\title{
Accounting and Finance Review
}

Journal homepage: www.gatrenterprise.com/GATRJournals/index.html

Acc. Fin. Review 1 (1) $59-65$ (2016)

\section{Revealing the Accounting Existence Through Debt-Receivable Practice at Majapahit Kingdom Era (1350)}

\author{
Novrida Qudsi Lutfillah ${ }^{1 *}$, Eko Ganis Sukoharsono ${ }^{2}$, Aji Dedi Mulawarman ${ }^{3}$ and Yeney \\ Widya Prihatiningtias ${ }^{4}$ \\ ${ }^{1}$ Doctoral Candidate of Economic and Business Faculty, Brawijaya University, 65142, Indonesia \\ ${ }^{2}$ Professor of Brawijaya University, 65142, Indonesia \\ ${ }^{3,4}$ Brawijaya University, Malang, 65142, Indonesia
}

\begin{abstract}
Objective - The Kingdom of Majapahit was a phenomenal civilization in the Indonesian history. Accounting was then practiced in the everyday life of the kingdom. The purpose of this study is to explore the accounting practices of debtreceivable accounts during the Majapahit Kingdom era of 1350 and to find the values behind their use.

Methodology/Technique - This study is a historical qualitative study. Its primary source of data are inscriptions and legislation manuscripts taken from the Kutara Manawasastra of the Majapahit era. Historical analysis is used to analyze data with historiography so as to expose the results of the historical research. This will help to reveal the underlying values in debt-receivable practices in the era.

Findings - The findings of this study reveal that the values of debt-receivable accounts being practiced in the Majapahit era comprise the social, economic and spiritual dimensions. The trust and spiritual values were practiced as a means to tie the mutual benefits between creditors and debtors.
\end{abstract}

Novelty - The findings reveal the accounting existence of the historical past.

Type of Paper: Review

Keywords: Debt; Receivables; Accounting History; The Kingdom Of Majapahit, Trust; Spiritual Values.

JEL Classification: H63, M41.

\section{Introduction}

Accounting history research has become a phenomenal topic among accounting researchers (Parker, 1997, 1999; Fleischman \& Radcliffe, 2005; Napier, 2006). Accounting history is the evolution study of the thinking processes, practices and institutions which emphasizes on the dynamic interaction between accounting and its environment as the central point (Someya, 1989). Through the unifying force of the past, present and future, such studies can provide information on thought history and contemporary accounting practices (Carnegie \& Napier, 2012).

\footnotetext{
* Paper Info: Received: October 4, 2016

Accepted: December 24, 2016

* Corresponding author:

E-mail: vrie_dha05@yahoo.com

Affiliation: Economic and Business Faculty, Brawijaya University, Indonesia
} 
Accounting existence in a society is strongly influenced by many factors. It is a system of the economic, social, political, and legislative practices of a society and it can be influenced by the culture, perception and values practised in a society considerably (Schroeder et al., 2009). In their study, Mathews and Parera (1993, p. 68) note that: "Although the conventional view is that accounting is socially constructed as a result of social, economic, and political events, there are alternative approaches which suggest that accounting may be socially constructing". This statement implies that accounting has two sides. On the one hand, accounting can be formed by the environment (socially constructed) and on other hand, the development of accounting is influenced by social factors such as economic and it simultaneously, creates the environment (socially constructing). This implies that accounting is recognised as a discipline of science and practice and it is the social values practiced by that society that also develops accounting. Social concepts in past decades have evolved significantly in accounting. These factors influence the direction and value of accounting considerably (Hopwood, 2005; Potter, 2005). Those values allow accounting research to be conducted through a number of factors encompassing cultural, social and political factors but these are done differently (Hopwood, 2005). Accounting researchers who adopt this perspective usually reward the unique characteristics of accounting by putting emphasis on the importance of the local scope of awareness and the factors that make up the specific accounting changes (Potter, 2005). Such research discourse has shown that accounting has linkage with the social context and that the accounting techniques used at that time to frame the economic and business events consists of measuring, recognizing and reporting those practices.

In the attempt to reveal the existence of accounting practices in a historical past, it is deduced that the debtreceivables applied during the Majapahit era could be reflected through the role of the accounting discipline via social, cultural and economic factors. In the context of this study, accounts payable is the activity to borrow or lend a sum of money and this involves two parties, the lender and the borrower (Totanan, 2004). Trade relation development makes the debt-receivable practices create more debts in the Majapahit kingdom.

Historically, the Majapahit kingdom was founded in 1293 AD at Tarik Forest, Mojokerto, East Java by Raden Wijaya who was the first king.). It was one of the famous kingdoms in Java with the age range of about 2.5 century (years 1293-1525) and it was ruled by 12 kings (Adji, 2013, p. 12). Another scholar, Panji (2015) suggests that the Majapahit kings had acted wisely in deciding cases including cases involving accounts payables. The Majapahit kings had referred to the Kutara Manawasastra book as a law resource and this practice showed the king's role as protector of the people who expected royal security.

As mentioned earlier, the purpose of this study is to determine accounting existence through debt-receivable practices noted in the Majapahit Kingdom and to find the values behind them. The reason for choosing the Majapahit kingdom is consistent with the emergence of a sense of national consciousness. The focus on the Majapahit kingdom is to satisfy the urge for further exploration as it is hoped that the outcome of this study will be able to demonstrate the valuable contributions of the past. Looking at historical practices of accounting can enable a better understanding of how the accounting environment operated then. More specifically, it could serve as the foundation towards developing a reflexive relationship involving accounting and the economic and social system and culture of a society.

\section{Methods}

This study is qualitative in nature because such study cannot be studied statistically or quantitatively (Basrowi \& Suwandi, 2008). The historical research method (Kuntowijoyo, 2013, p.78) is chosen, in line with the purpose of this study. The historical research method is applied by troubleshooting procedures through data and past relics as a means to understand events or circumstances of that period. Data of debt-receivables in the Majapahit era were retrieved from written sources, both primary and secondary. Primary data were based on the inscriptions of the Majapahit era while secondary data were based on the Majapahit legislation text called the Kutara Manawasastra which has been translated by Hakim (2004). Historical interpretation is also called historical analysis and the term, analysis, by itself, means outlining. This terminology differs from the word, synthesis, which means to unite. The distinction is made because analysis and synthesis are seen as the 
main methods of interpretation. In the context of this study, the analyzed data, when ready to be used, will give meanings. Historiography is the final episode and the climax of a historical research activity series. This section explains the historical research results based on evidence extracted from the historical data sources.

\section{Result}

Debt-receivables refer to money borrowed from other people in the perspective of the borrower while credit receivables refer to the money lent to other, as viewed from the creditor. The term credit was derived from the Greek word "credere" which means confidence and credo which means belief. Thus, belief in debts refer to principles held by a person in relation to trade (Totanan, 2014). The credit term later became fully adopted into economic terms as a means to define receivables or lending to any person or entity. The opposite of receivable is debt. The statement of the Financial Accounting Standards (SFAS) No. 1 defines debt as the company's obligation which arise out from acts or transactions in the past to get assets or services. Repayments will be made in the future either by cash, assets of certain other services or by creating new debts. The KBBI defines debt as: 1) the money borrowed from others, and 2) the obligation to pay back for what has been received.

Debt-receivables is thus referred to the original meaning as seen in the interactions of a social system that was based on trust. If the truster gives credit to the trustee, it means there is trust between the two parties. Debtreceivable practices, basically, is confidence to lend and receive payment. An economic action involving debts is a form of social action and it is situated socially including social economic institutions deconstruction (Damsar, 2011, p.31).

Human beings are social beings who need help from others to meet their needs. This assistance can be a loan or debt. Debt-receivables in the Majapahit era refer to something that was allowed but it must be done carefully. Accounts payable was stipulated in the articles of the manuscripts of the legislation of Religion and Kutaramanawa. This book was held in the Majapahit Kingdom during the reign of Hayam Wuruk. The Bendosari Inscription issued by Hayam Wuruk King, as the third Majapahit king, was to show the Kutara Manawa book being used as a source of law or legislation. The inscription is written below (Panji, 2015, p. 210):

“...makatanggwan rasagama ri sang hyang kutaraa manawa adi, manganukara prawetyacara sang pandita wywaharawiccheda karing malama...”

The meaning: based on the contents of the noble book of Kutara Manawasastra, we must follow the example of the pastor's discretion in deciding disputes.

Furthermore, the Trowulan inscription dated 1358 also mention the Kutara Manawasastra book as a source of law. The inscription is written below:

“...ika kabeh Kutara Manawa adisastra wiwecana tatpara kapwa sama-sama sakte kawikak saning sastra makadi kutara manawa..."

The meaning: all experts have the aim to interpret the statute books of the Kutara Manawa. They were able to interpret the meaning of the statute books as the Kutara Manawa.

As a law resource for Majapahit, the Kutara Manawasastra book discusses various issues of criminal and civil activities. The book consists of 272 chapters where one chapter complies with the others (Muljana, 1976). The Kutara Manawasastra legislation talks about accounts payable as mentioned from Article 117 to Article 153 (Hakim, 2008). 


\section{Discussion}

\subsection{Debt-Receivable Provisions}

Article 117 establishes several requirements that must be done in debt-receivables which can only be transacted on a certain day i.e. Monday and Thursday. There is preparation for someone who wants to get debt or to receive the loan. The person who will borrow the money was required to clean the body with shampoo and face wash. Cleansing themselves before the debt is to make the borrowers aware that these actions were performed in a stable state of mind, vision and healthy. The initial condition must be met in order to have debt receivable transactions be executed.

Implementation of the debt-receivable cannot be separated from the recording activity. The events must be recorded by the debt-receivable clerk as required in Article 117 (Muljana, 1976, p.131) as stipulated below:

... the clerk must not forget to note the debtor's name, the village where he lives, amount of debt, date of month, week, the day, year, especially the total debt along with interest, witnesses and characteristics of debtor, when beginning to make debt. The note name is Pawitan (letter of credit).

The Letter of Credit or Pawitan includes all the information about the debtor and the name of the witness. The Letter of Credit is made by the debtor and it basically comes from the debtor as a sign of debt recognition. Judging from the debtor, the Pawitan is a letter of credit while for the creditor it is indebted receivable account Pawitan. Payable is recorded to give guarantee in order to avoid mistakes or forget either the amount of debt or the repayment. In addition, recording is required so that parties find it easy to sue the debtor for repayment when they are due. In addition to writing evidence, accounts payable also need witnesses. This is done to anticipate dispute if one party denies the agreement and the witness will give testimony to the truth of the agreement.

Article 143 explains the incident of debt-receivable to free a person from the debt by stealing or ordering to steal the Letter of Credit. Then it is considered a theft and he will be fined forty thousand, besides having to pay a debt doubled to the original debt as guilt and repayment of debt. Other events such as if the Letter of Credit is damaged by insect, is lost or burnt; then the debtor must notify the creditor and shall replace it with a new Letter of Credit. Furthermore, Article118 regulates the receivable evidence as follows:

... the debtor should hold three kinds of receivable evidences. What is the evidence? 1 . Receivable evidence in the form of a witness; 2 . Receivable evidence in the form of writing; 3 Receivable evidence in the form of interest payment evidence...

The Letter of Credit, witnesses and interest payment evidence are three kinds of evidence receivable that should be kept well and are owned by the creditor. Without these, the receivable can be declared as never happened according to law. The strength of the three receivable evidences is stratified. The lowest powerful is witness. The Letter of Credit is less powerful than the interest payment evidence. With the three receivables evidence, the debt can be charged up to children and grandchildren of the debtor (Muljana, 1976).

These conditions indicate that debt-receivables must be done with a clean heart, followed by note and witnesses. The provisions made in debt-receivables are a manifestation of accountability. The principle of responsibility or accountability is based on the trust concept, a result of human transactions with God which has helped human responsibility to develop as mandated actors to conduct accountability implications of what that has been mandated and done to related parties. 


\subsection{Debt Measurement}

Measurement is the process to give attribute to the debt value. Attribute value for debt is a monetary value. In practice, debt can be either an item or money debt, food debt accompanied by an agreement to repay in various kinds such as crops and livestock. If the debt items are assessed with cash then the payment of interest and repayment of debt is same as money debt. But if the item debt is not rated with money, then it is regulated by following the law:

- Article 126: Whoever has rice debt and did not immediately return it, it must be doubled each year; The payment deadline is five years.

- Article 127: Anyone who does not immediately pay the rice debts, after five years should return the debt five times.

- Article 125: If the debt is mares, female buffalo, cows, for every three years it must be returned in double.

Debt interest was prevalent in the Majapahit era. Article 122 regulates the amount of interest that may be charged for debt. The highest interest of a thousand debt money for every month is twenty, forty, and fifty.

The lowest interest rate is twenty and the highest interest rate is fifty for a thousand debt loans made each month. If the interest is more than as stipulated by law, the debtor is considered as greedy and not complying with the law. Article 119 says that if the debtor took interest that is higher, then the creditor is called greedy and considered not complying with the laws in force. People who do not comply with the laws in force will not get the goodness of life as mentioned in Article 120:

Debtor who is obedient to receivables laws, he makes fertile to gold and silver (possessions), that is benefits as stated by legislation teachings.

These explanations show that the debtor should be able to use as best as he can the money debt he has and to be aware that a loan is a trust that must be returned. In addition, a debtor should try to pay off the debt as soon as possible when he has the ability to pay debt. People who postpone debt repayments when they are able to pay will be included as those who do evil in life.

\subsection{Debt Settlement}

The debtor's obligation is to pay the debt to the creditor. The debtor is considered in default if he makes any denial of repayment to the loan in the credit agreement. Denying debt is cheating. Article 133 stipulates double fine to those who deny to pay the principal. Furthermore, other fines is four hundred for one hundred debts; one thousand to four thousand debt and so on. It is a multiple by four amount of fine payment. Debt collection should be done in a good way. A creditor is not allowed to act impolitely to the debtor although the debtor is deliberately intending not to pay his debts. Article 140 regulates to forbid violence action to collect debts.

... the debt should be billed with sweet words for first time, for second time creditor should find way to collect debt, third time should be threat with complaint; fourth time should avoid the quarrel possibility; fifth time bring him out and take all the money in him.

The first thing to do when collecting debts is to use sweet words. If sweet words fail, the creditor is recommended to seek other ways to collect the debt and to avoid quarrels. If all good ways did not work, then the debtor can be threatened with complaints because debt-receivable affair is regulated by the law. Furthermore, if it is not successful, the creditor is authorized to complain to the court. In this case, the debtor will be forced to give all of his money to pay off the debts and he will also be subjected to criminal punishment 
according to the law. The debt-receivables of the Majapahit era have a prevalent agreement about someone who becomes the debt's underwriter if the debtor is unable to pay off the debt. The underwriter of obligations is specified in Article 135:

Whoever guarantees that the debtor would not cheat. If the debtor was a cheat, underwriter must pay his debt. Billing is not doubled, if the person was dead and the debt is not inheritable by his grandchildren...

The underwriter's obligation is to pay off all the debts with interest to the creditor if the debtor cannot pay the debt or died. In this case, the person can be charged when it is considered that debt payments may no longer be obtained from the borrower. There are people who are willing to bear the debts of others and they are the close kins or relatives of the debtor.

Denying a debt and collecting debts for a non debtor is an action that harm others. This is usually solved amicably by both parties through negotiations. If the negotiation fails, then the affair is settled by authorities who will resolve the conflict through swearing. The Majapahit society is very obedient and afraid when under the power of oaths as oaths have a direct accountability to God whom the people strongly believe in. This is explained in Article 145:

"Those who deny the debts and collecting without debt, such person does not know his darma. If one of them is involved and do not budge, he is ordered by the king to swear to God ".

Taking an Oath to God plays an important role in the settlement of debt-receivable fraud. This condition shows that if the two sides have agreed on a debt receivable and the conditions attached to the agreement, then they are obliged to fulfil the agreement because it is one form of responsibility to a fellow human being and also to God.

\subsection{Reflection the Practical Value of Debt-Receivable in Majapahit Era}

The meaning interpreted from the result for debt-receivable practices during the Majapahit era is stipulated in the Kutara Manawasastra book which contains values and spiritual mandates. Trust and spiritual values are associated with the existence of the Pawitan and witnesses as a form of debtor accountability to others and God. By itself, a debtor should be aware that a debt is a trust that must be returned because debt-receivable is an agreement that not only shapes the engagement between the debtor and creditor but also with God. The behavior underlying the debt-receivable practices during the Majapahit era is based on attitude which puts the needs of the collective rather than the individual self and this is without ulterior motives.

Debt receivable is an action to help other people reduce their difficulties as well as others who are in trouble and have strong kinship on both sides. This attitude is called the karyenak tyasing sesama behavior namely life behavior which prioritize the interests of others wholeheartedly and without ulterior motives in the aim to address welfare (Endraswara, 2013, p.63).

\section{Conclusions and Limitations Research}

The accounting practices for debt- receivable accounts during the Majapahit era can be classified into the social, economic and cultural dimensions. For the social dimension, the debt-receivable accounts were practiced by the people of the Majapahit era where lending and borrowing were mutual assistance of the people. Mutual assistance was a social value embedded in the everyday social lives. For the economic dimension, the debt-receivable accounts were economic transactions where the people of the Majapahit era exchanged their economic commodities such as money coins and agricultural products. For the cultural dimension, debt-receivable accounts served as a model where trust and spiritual values existed among the people as a means to tie their brotherhood. 
The Kutara Manawasastra book of the Majapahit legislation was used intensively to rule their activities including the transactions of debt-receivable practices. This study finds that three dimensions: the social, economic and cultural dimension of accounting practices were used for debt-receivable transactions during the Majapahit era. In particular, trust and spiritual values of the cultural dimension underlie the debt-receivable practices in the Majapahit era. Both values were based on the karyenak tyasing sesama behavior for neighbor ie debt-receivable is based on the altruistic behavior of putting other's interest above their individual self interest.

\section{References}

Adji, K. B. (2013). Majapahit: menguak Majapahit berdasar fakta sejarah. Yogyakarta: Araska.

Basrowi, S. (2008). Memahami penelitian kualitatif. Jakarta: Rineka Cipta.

Carnegie, G. D., \& Napier, C. J. (2012). Accounting's past, present and future: the unifying power of history. Accounting, Auditing \& Accountability Journal, 25(2): 328-369.

Damsar. (2011). Pengantar sosiologi ekonomi. Jakarta: Kencana Prenada Media.

Endraswara, S. (2013). Метауи hayuning bawana: laku menuju keselamatan dan kebahagiaan hidup orang Jawa. Yogyakarta: Narasi.

Fleischman, R. K., \& Radcliffe, V. S. (2005). The roaring nineties: accounting history comes of age. The Accounting Historians Journal, 61-109.

Hakim, L. (2004). Konstitusi Majapahit. Malang: UMM Press.

Hopwood, A. G. (2005). After 30 years. Accounting, Organizations And Society, 30(7-8), 585-586.

Kuntowijoyo. (2013). Pengantar ilmu sejarah. Yogyakarta: Tiara Wacana.

Mathews, M.R., \& Perera, M.H.B. 1993. Accounting Theory And Development. Melbourne: Thomas Nelson Australia.

Muljana, S. (1976). Perundang-undangan Majapahit. Jakarta: Bhratara.

Napier, C. J. (2006). Accounts of change: 30 years of historical accounting research. Accounting, Organizations And Society, 31(4-5): 445-507.

Panji, T. (2015). Kitab sejarah terlengkap Majapahit. Yogyakarta: Laksana.

Parker, L.D. (1999). Historiography for the new millennium: adventures in accounting and management. Accounting History, 4 (2): 11-42.

Parker, R. H. (1997). Research needs in accounting history. The Accounting Historians Journal, 4(2): 1-28.

Potter, B. N. (2005). Accounting as a social and institutional practice: perspectives to enrich our understanding of accounting change. Abacus, 41(3): 265-289.

Schroeder, R.G., Clark, M.W., \& Cathey, J.W. (2009). Financial accounting theory and analysis-text and cases. USA: John Willey\& Sons, Inc.

Someya, K. (1989). Accounting revolutions in Japan. The Accounting Historians Journal, 16(1): 75-86.

Sukoharsono, E. G. (1995). A Power and Knowledge Analysis of A power and knowledge analysis of Indonesian accounting history: social, political and economic forces shaping the emergence and development of accounting. Ph.D Dissertation. University of Wollongong.

Totanan, C. (2014). Utang-piutang non kontraktual dalam budaya rambu solo'(studi fenomenologi pada Masyarakat Toraja). Ph.D Disesertation. Malang, Brawijaya University. 